\title{
Weed suppression by green manure in an agroecological system ${ }^{1}$
}

\author{
Katia Maria Garicoix Recalde ${ }^{2}$, Leandro Flávio Carneiro ${ }^{3}$, Daniella Nogueira Moraes Carneiro ${ }^{4}$, \\ Guilherme Felisberto ${ }^{5}$, Jaqueline Silva Nascimento ${ }^{6}$, Milton Parron Padovan ${ }^{7}$
}

http://dx.doi.org/10.1590/0034-737X201562060006

\begin{abstract}
Green manure promotes efficient suppression of weeds, but green manure species can exhibit distinct behaviors, depending on the environmental conditions. This study aimed to evaluate the potential of soil mulching and weed suppression by spring/summer green manure species grown in the spring/summer season, at different growth stages and after management (cut), for 90 days during the cassava crop cycle. The study was carried out in the 2010/2011 season, in a system managed under agroecological principles. The treatments consisted of different green manure species and arrangements: Crotalaria juncea, Cajanus cajan, Canavalia brasiliensis, Canavalia ensiformis, Pennisetum americanum, Crotalaria juncea and Pennisetum americanum intercropped; Mucuna aterrima, Sorghum bicolor, a mixture of all the green manures in study and a control plot under fallow. The experiment was arranged in a randomized block design with four replications. The evaluations of the soil cover either by the green manures or weeds were performed at 45, 90 and 105 days after the emergence of the green manures. The cassava crop was planted under reduced tillage system at 11 days after the cut of the green manures. The percentage of soil covered by weeds and the dry matter produced were evaluated at 30,60 and 90 days after planting. The results showed that the green manures had a suppressive effect on weeds during their life cycle, as well as during the first months after its management (cut), composing the mulch.
\end{abstract}

Key words: green manure, soil cover, mulching, agroecological principles.

\section{RESUMO}

\section{Supressão de plantas daninhas pela adubação verde em sistema sob bases agroecológicas}

A adubação verde é capaz de promover expressiva supressão de plantas daninhas, todavia, as espécies de adubos verdes podem apresentar comportamentos distintos, dependendo das condições edafoclimáticas. Este trabalho teve como objetivo avaliar o potencial de cobertura do solo e de supressão de plantas daninhas, por adubos verdes cultivados na primavera/verão, em diferentes estádios de desenvolvimento e após o seu manejo (corte), durante 90 dias do ciclo da mandioca. O estudo foi desenvolvido no ano agrícola 2010/2011, em um sistema manejado sob princípios agroecológicos.Os tratamentos foram constituídos por espécies de adubos verdes e por arranjos: Crotalaria juncea (crotalária); Cajanus cajan (feijão-guandu); Canavalia ensiformis (feijão-de-porco); Canavalia brasiliensis (feijão-bravo-do-ceará); Pennisetum americanum (milheto); consórcio entre Crotalaria juncea e Pennisetum americanum, Mucuna aterrima (mucuna-preta); Sorghum bicolor (sorgo-forrageiro), mistura de todos os adubos verdes anteriormente citados e uma parcela testemunha em pousio. Utilizou-se o delineamento de

\footnotetext{
Reiceved on 09/04/2014 and Approved on 09/21/2015

This work is part of the first author master's thesis.

${ }^{2}$ Agência de Desenvolvimento Agrário e Extensão Rural de Mato Grosso do Sul, Mundo Novo, Mato Grosso do Sul, Brazil. vitoria05@hotmail.com

${ }^{3}$ Universidade Federal de Goiás, Parque Industrial, Jataí, Goiás, Brazil. leoflacar@yahoo.com.br

${ }^{4}$ Universidade Federal de Goiás, Parque Industrial, Jataí, Goiás, Brazil. daninog27@ yahoo.com.br

Universidade Federal de Goiás, Parque Industrial, Jataí, Goiás, Brazil.

${ }^{6}$ Universidade Federal da Grande Dourados, Dourados, Mato Grosso do Sul, Brazil. jaque24nascimento@ hotmail.com

Empresa Brasileira de Pesquisa Agropecuária, Embrapa Agropecuária Oeste, Dourados, Mato Grosso do Sul, Brazil. milton.padovan@embrapa.br

* Corresponding author: gfelisberto@outlook.com
} 
blocos ao acaso, com quatro repetições. As avaliações de cobertura do solo pelos adubos verdes e pelas plantas daninhas foram realizadas aos 45, 90 e 105 dias após a emergência dos adubos verdes. Aos 11 dias após o corte dos adubos verdes, foi implantada a cultura da mandioca, por meio de cultivo mínimo. Aos 30, 60 e 90 dias após o plantio dessa cultura foram realizadas avaliações referentes à taxa de cobertura do solo pelas plantas daninhas e matéria seca dessas plantas. Os resultados obtidos evidenciaram que as espécies de adubos verdes exerceram efeito supressor nas plantas daninhas durante o ciclo de vida, bem como nos primeiros meses após seu manejo (corte), compondo a cobertura morta.

Palavras-chave: adubos verdes, cobertura do solo, cobertura morta, princípios agroecológicos.

\section{INTRODUCTION}

Weed management in agroecosystems is performed in agroecological bases, without the use of herbicides to keep them at levels that do not pose competition with crops of economic interest for environmental resources such as water, nutrients and sunlight (Padovan \& Almeida, 2006).

Cassava, an important source of starch for the world population, has a slow initial development, enabling the emergence and development of weeds in the crop area. According to Albuquerque et al., (2008), among biotic factors, these undesirable plants are a major component of the agroecosystem of the crop and interfere with the development and yield of cassava.

Because of the impact on the cassava crop caused by weeds in agroecological systems, a proper weed management should use strategies such as the rational use of soil cover (Borghi et al., 2008), which can delay weed germination and suppress the development of invasive species.

Green manure has been used in different agricultural systems to assist in the elimination of weeds, through allelopathic effects, restricting growth space and competition for water, light, oxygen and nutrients and suppressing reinfestations (Timossi et al. 2011),

The germination, growth and development of weeds present in the soil seed bank can be inhibited or stimulated by allelopathic influence of mulch. This allelopathic activity depends on the quality and quantity of plant material deposited on the soil surface, the soil type, microbial population, climatic conditions and the composition of the community of weed species (Monquero et al., 2009).

The most common allelopathic effects provided by the mulch vary from those less severe such as leaf chlorosis, reduced tillering, shrinking or deforming of roots, to those most desirable for farmers such as reduction of germination, seedling death and reduction of the vigor of the weed (Erasmo et al., 2004).

Santos et al. (2007) pointed out the importance of knowing the behavior of the green manure species to be used in pre-cultivation to obtain a good production, regardless of the species cultivated in succession, as well as to improve the soil conditions of the crop area.

Therefore, the aim of this study was to evaluate the potential for soil cover and weed suppression of green manures grown in the spring/summer season, at different stages of development and after cutting for 90 days during the cassava cycle (Manihot esculenta).

\section{MATERIAL AND METHODS}

The study was conducted in the agricultural year 2010/ 2011 , in the municipality of Itaquiraí, State of Mato Grosso do Sul, in the geographical coordinates of $23^{\circ} 028^{\prime} \mathrm{S}$, $54^{\circ} 011^{\prime} \mathrm{W}$ and $340 \mathrm{~m}$ of altitude, in a typic Haplortox (Santos et al., 2013), sandy texture (852 $\mathrm{g} \mathrm{kg}^{-1}, 37 \mathrm{~g} \mathrm{~kg}^{-}$ ${ }^{1}$ and $111 \mathrm{~g} \mathrm{~kg}^{-1}$ sand, silt and clay, respectively).

In this ecoregion, the beginning of the rainy season is usually in October, stepping up from December to February and reducing significantly in March and April. From June to August, rainfall occurs predominantly at very low levels, while April and September can be considered as a transition between the rainy and dry seasons (Fietz \& Fisch, 2008).

The soil of the experimental area, at the planting of green manures, had the following values of chemical attributes at a depth of $0-20 \mathrm{~cm}: \mathrm{pH}\left(\mathrm{H}_{2} \mathrm{O}\right)=5.8$; $\mathrm{Al}=0.1 \mathrm{cmol}_{\mathrm{c}} \mathrm{dm}^{-3} ; \mathrm{Ca}=1.4 \mathrm{cmol}_{\mathrm{c}} \mathrm{dm}^{-3} ; \mathrm{Mg}=1.0 \mathrm{cmol} \mathrm{dm}_{\mathrm{c}}^{-3}$; $\mathrm{K}=0.24 \mathrm{cmol}_{\mathrm{c}} \mathrm{dm}^{-3} ; \mathrm{P}$ (Mehlich-1) $=9.6 \mathrm{mg} \mathrm{dm}^{-3}$ and M.O. $=10.85 \mathrm{~g} \mathrm{~kg}^{-1}$.

The experiment was arranged in a $10 \times 3$ factorial randomized blocks design, with four replications, ten treatments and three evaluation periods. Each experimental unit was $10 \mathrm{~m}$ wide and $20 \mathrm{~m}$ long, with the planting rows spaced at $0.45 \mathrm{~m}$ and sowing density as 
recommended by Calegari et al. (1993) for each species, without fertilization. Green manure sowing was carried out on $24 / 10 / 2010$.

The treatments consisted of: Crotalaria juncea (sun hemp); Cajanus cajan (pigeon pea); Canavalia ensiformis (jack bean); Canavalia brasiliensis (Brazilian jack bean); Pennisetum americanum (pearl millet); intercrop of Crotalaria juncea and Pennisetum americanum (50\% of the density recommended for each species in monocrop); Mucuna aterrima (velvet bean); Sorghum bicolor (forage sorghum); mixture of all green manures used in the study (Canavalia ensiformis, Canavalia brasiliensis, Mucuna aterrima, Cajanus cajan, Crotalaria juncea, Pennisetum americanum and Sorghum bicolor) and a control plot under fallow (weed vegetation, predominantly Bidens pilosa, Brachiaria decumbens, Croton glandulosus, Cenchrus echinatus and Sida cordifolia).

The evaluations of soil cover by green manure and occurrence of weeds were performed at 45, 90 and 105 days after emergence (DAE) of green manure. At 105 DAE, by the cutting time of the green manure, most species studied were at the end of flowering stage and the beginning of grain formation.

A $0,50 \mathrm{~m}^{2}$ wooden frame, with a cotton thread grid evenly spaced at intervals of $5 \mathrm{~cm}$ was used to observe the presence of plant cover, according to Alvarenga et al. (1995). In each treatment, the replications consisted of four launches at random within the harvest area, totaling $1 \mathrm{~m}^{2}$ of area sampled. First, this procedure was performed to evaluate the soil cover by the green manure and then to measure the occurrence of weeds in each evaluation period.

The evaluations were carried out to assess the soil covering rate by the weeds and dry matter yield, after the green manure cut and at 30, 60 and 90 days after the cassava planting (DAP). The plants of each treatment were cut close to the ground, packed in paper bags and dried in a forced ventilation oven at $65^{\circ} \mathrm{C}$ to constant weight to determine the dry matter.

Data were subjected to analysis of variance and the significant results by the $\mathrm{F}$ test $(\mathrm{P}<0.05)$ were analyzed by the Scott-Knott test $(\mathrm{P}<0.05)$.

\section{RESULTS AND DISCUSSION}

At 45 days after emergence (DAE), the treatments with Pennisetum americanum, Crotalaria juncea + Pennisetum americanum and the mixture of the green manures provided the highest soil cover percentages; at $90 \mathrm{DAE}$, the mixture of green manures kept the highest percentages, with Mucuna aterrima also standing out. At $105 \mathrm{DAE}$, the mixture of green manures,
Mucuna aterrima and Canavalia brasiliensis were the treatments with the best performance in soil cover (Table 1).

The performance of Pennisetum americanum at 45 days corroborates data found by Calvo et al. (2010) and may be related to its photosynthetic mechanism. $P$. americanum is a $\mathrm{C} 4$ tropical grass and responds photosyntheticaly better to high light intensity than the C3 plants, such as legumes.

Studies conducted in different regions of the country found effective soil cover by Pennisetum americanum, both in monoculture (Torres et al., 2008) and intercropped (Oliveira et al., 2002).

Padovan et al. (2012) reported that Pennisetum americanum had the highest accumulation of shoot dry matter at $75 \mathrm{DAE}$ (9.24 $\left.\mathrm{t} \mathrm{ha}^{-1}\right)$; however, the grass had already accumulated good amount of mass from the 45 DAE, reaching $4.2 \mathrm{t} \mathrm{ha}^{-1}$ and showing that it is a species of rapid initial development.

Pennisetum americanum decomposes rapidly under favorable environmental conditions compared with other grasses such as some Brachiaria species (Pacheco et al., 2011), which contributes to low weed suppression.

Sorghum is another cover crop used in the study, which, despite being a C4 plant, had lower development than Pennisetum americanum at 45 DAE, with results similar to those of Canavalia ensiformis. Some authors observed that the initial growth of sorghum occurs slowly, at 30 and 43 days after sowing (Calvo et al., 2010), which corroborates the behavior of this grass found in this study.

The interaction of legumes with grasses such as in the treatments of Pennisetum americanum + Crotolaria juncea and the mixture of green manures also performed well for soil cover at 45 days. Nascimento \& Mattos (2007), studying the biomass production and weed suppression by cover crops, concluded that the intercrop of grasses with legumes such as Pennisetum americanum with dwarf pigeon pea showed the greatest accumulation of shoot dry matter, which recommends the intercrop when the objective is to incorporate large amounts of biomass to the soil.

At 95 DAE, the mixture of green manures and Mucuna aterrima stood out for soil cover (Table 1). This performance can be related to the interaction of legumes with nitrogen-fixing bacteria, which enables substantial amounts of $\mathrm{N}$ and significantly contributes to its successful development.

Okito et al. (2004) observed that the contribution of biological nitrogen fixation (BNF) of Mucuna aterrima was $69 \%$, which was close to the value later found by Silva et al. (2011), of 67\%, working with green velvet bean (Mucuna pruriens), and demonstrating the 
potential of BNF and $\mathrm{N}$ accumulation of this genus. For this reason, authors such as Nascimento \& Mattos (2007) have recommended the use of Mucuna aterima when there is high incidence of weeds in the crop area, not only for its good nitrogen fixing ability, but mainly by its high potential for weed suppression.

At 105 DAE, the treatments with Mucuna aterrima, mixture of green manures and Canavalia brasiliensis gave the best soil cover. In studies with Mucuna and Canavalia brasiliensis, some characteristics in the field were reported by different authors such as the large biomass production and hardiness during water stress period, because their the root system acts aggressively, absorbing water and nutrients at greater depths in the soil (Alvarenga et al., 1995).

Favero et al. (2001), studying several legumes in weed control, found that Mucuna aterrima had greater potential for soil cover and weed suppression, besides that the indeterminate, creeping herbaceous, prostrate growth habit of these plants gives greater capacity to their branches and leaves to spread better and closer to the ground. For this reason, there is a greater radius of control over weeds, since they have good ability to smothering and aggression, decreasing its spontaneous population by competing in particular for sun light.

In a study developed in different ecoregions in Mato Grosso do Sul, Padovan et al. (2011) found that the Canavalia ensiformis reached the maximum accumulation of shoot dry matter at 90 DAE, which certainly favors a greater soil cover, at the pod formation stage.

Duarte Junior \& Coelho (2008) evaluated green manures for no-till system in Campos, State of Rio de Janeiro. They reported greater soil cover rate provided by Crotalaria juncea, around $87 \%$ at 35 days after the emergence, $15 \%$ higher than Canavalia ensiformis and 40\% higher than Mucuna aterrima. Favero et al. (2001) found that Canavalia brasiliensis, followed by Mucuna aterrima and Canavalia ensiformis were the legumes with higher biomass production, while Mucuna aterrima showed the greatest potential for soil cover and weed suppression.

The findings of this study and others abovementioned, from different regions of the country, can explain the behavior of green manures used for soil cover, because grasses such as Pennisetum americanum showed good soil cover in a few days after emergence, but within 90 days were overcome by legumes which remained in the system with efficiency for up to 105 days.

Choosing the green manure can vary according to the needs of the farmer, if a rapid ground cover is desirable, Pennisetum americanum stands out as the most suitable species; however, if the objective is the elimination of weeds, providing cover above $90 \%$ over 90 days, then Mucuna aterrima and the mixture of green manures are more suitable.

The lowest percentages of soil cover and dry matter produced by the weeds (Tables 2 and 3), at 45 DAE, occurred in the treatments with Pennisetum americanum, Pennisetum americanum + Crotalaria juncea and the mixture of green manures.

At 90 DAE, the lowest incidences of weeds were recorded under the mixture of green manures, Pennisetum americanum and Mucuna aterrima and, at 105 DAE, Canavalia brasiliensis, Mucuna aterrima and the mixture of green manures promoted the best weed suppression, remaining only a few scattered plants, providing lower soil cover.

Table 1: Soil cover by green manures at different times after seedling emergence in Itaquiraí, Mato Grosso do Sul agricultural year: 2010/2011

\begin{tabular}{lccc}
\hline & & Days after emergence of green manures & $\mathbf{1 0 5}$ \\
\cline { 2 - 4 } Green manures & $\mathbf{4 5}$ & $\mathbf{9 0}$ & Soil cover (\%) \\
\cline { 2 - 4 } & & $80.0 \mathrm{c} \mathrm{A}$ & $81.2 \mathrm{c} \mathrm{A}$ \\
\hline Crotalaria juncea & $53.7 \mathrm{~b} \mathrm{~B}$ & $71.2 \mathrm{~d} \mathrm{~B}$ & $80.2 \mathrm{c} \mathrm{A}$ \\
Cajanus cajan & $38.7 \mathrm{c} \mathrm{C}$ & $81.2 \mathrm{c} \mathrm{B}$ & $92.2 \mathrm{a} \mathrm{A}$ \\
Canavalia brasiliensis & $41.2 \mathrm{c} \mathrm{C}$ & $81.2 \mathrm{c} \mathrm{A}$ & $75.7 \mathrm{c} \mathrm{B}$ \\
Canavalia ensiformis & $56.2 \mathrm{~b} \mathrm{C}$ & $76.2 \mathrm{~d} \mathrm{~A}$ & $76.2 \mathrm{c} \mathrm{A}$ \\
Pennisetum americanum & $62.5 \mathrm{a} \mathrm{B}$ & $86.2 \mathrm{~b} \mathrm{~A}$ & $86.2 \mathrm{~b} \mathrm{~A}$ \\
P. americanum/C. juncea & $58.7 \mathrm{a} \mathrm{B}$ & $90.0 \mathrm{a} \mathrm{B}$ & $96.2 \mathrm{a} \mathrm{A}$ \\
Mucuna aterrima & $45.0 \mathrm{c} \mathrm{C}$ & $80.0 \mathrm{c} \mathrm{A}$ & $85.2 \mathrm{~b} \mathrm{~A}$ \\
Sorghum bicolor & $56.2 \mathrm{~b} \mathrm{~B}$ & $93.7 \mathrm{a} \mathrm{A}$ & $96.0 \mathrm{a} \mathrm{A}$ \\
Mixture of green manures & $60.0 \mathrm{a} \mathrm{B}$ & $00.0 \mathrm{e} \mathrm{A}$ & $00.0 \mathrm{~d} \mathrm{~A}$ \\
Fallow (control) & $00.0 \mathrm{~d} \mathrm{~A}$ & 5,7 & \\
\hline CV (\%) & &
\end{tabular}

* Means followed by the same small letter in the column and capital letter in the row are not significantly different at $5 \%$ by the Scott-Knott test. 
The low incidence of weeds under Pennisetum americanum at 45 DAE (Tables 2 and 3) has a strong relationship with the fact that this species has a fast initial growth, explaining the good performance both in monoculture and intercropping with Crotalaria juncea.

Meschede et al. (2007) evaluated different cover crops for weed suppression in the cerrado and found that Crotalaria juncea and Pennisetum americanum provided good suppression, promoting greater soil cover and maximizing light capture by the canopy.

The mixture of green manures also stood out at 45 DAE, since it is composed of species with different characteristics and rapidly promoted the elimination of most weed species. The mixture maintained its performance at $90 \mathrm{DAE}$ and was the most efficient treatment of this evaluation, resulting in lower rate of soil cover by the weeds. However, the good performance of Pennisetum americanum was maintained, as well as a significant development of Mucuna aterrima (Table 2).

The good performance of Mucuna aterrima at 90 DAE in weed suppression (Table 2) came from the effective soil cover (90\%) (Table 1). According to Fernandes et al. (1999), the ability of this legume to smother weeds and their allelopathic effects are critical in suppressing most weeds.

At 105 DAE, Mucuna aterrima and Canavalia brasiliensis promoted a great reduction of weeds (Tables 2 and 3). This performance may be associated with the ecology of these species, which have a twining and climbing habit, outcompeting and suppressing the

Table 2: Soil cover by weeds at different times after germination of green manures in Itaquiraí, Mato Grosso do Sul. Agricultural year: 2010/2011

\begin{tabular}{|c|c|c|c|}
\hline \multirow{3}{*}{ Green manures } & \multicolumn{3}{|c|}{ Days after emergence of green manures } \\
\hline & 45 & 90 & 105 \\
\hline & \multicolumn{3}{|c|}{ Soil cover $(\%)$} \\
\hline Crotalaria juncea & $31.2 \mathrm{~b} \mathrm{~A}^{*}$ & $16.2 \mathrm{~b} \mathrm{~B}$ & $14.2 \mathrm{c} \mathrm{B}$ \\
\hline Cajanus cajan & 43.7 a A & $21.2 \mathrm{~b} \mathrm{~B}$ & $14.5 \mathrm{c} \mathrm{C}$ \\
\hline Canavalia brasiliensis & $47.5 \mathrm{a} \mathrm{A}$ & $17.5 \mathrm{~b} \mathrm{~B}$ & $6.0 \mathrm{~d} \mathrm{C}$ \\
\hline Canavalia ensiformis & $30.0 \mathrm{~b} \mathrm{~A}$ & $18.7 \mathrm{~b} \mathrm{C}$ & $20.0 \mathrm{~b} \mathrm{~B}$ \\
\hline Pennisetum americanum & $21.2 \mathrm{c} \mathrm{A}$ & $11.7 \mathrm{c} \mathrm{B}$ & $20.0 \mathrm{~b} \mathrm{~A}$ \\
\hline P. americanum/C. juncea & $22.5 \mathrm{c} \mathrm{A}$ & $13.7 \mathrm{~b} \mathrm{~B}$ & $10.5 \mathrm{c} \mathrm{B}$ \\
\hline Mucuna aterrima & $47.5 \mathrm{a} \mathrm{A}$ & $8.7 \mathrm{c} \mathrm{B}$ & $2.8 \mathrm{~d} \mathrm{C}$ \\
\hline Sorghum bicolor & $31.2 \mathrm{~b} \mathrm{~A}$ & $13.7 \mathrm{~b} \mathrm{~B}$ & $11.2 \mathrm{c} \mathrm{B}$ \\
\hline Mixture of green manures & $22.5 \mathrm{c} \mathrm{A}$ & $4.2 \mathrm{~d} \mathrm{~B}$ & $2.8 \mathrm{~d} \mathrm{~B}$ \\
\hline Fallow (control) & 50.0 a C & 90.0 a B & 96.2 a A \\
\hline $\mathrm{CV}(\%)$ & & 15 & \\
\hline
\end{tabular}

* Means followed by the same small letter in the column and capital letter in the row are not significantly different at $5 \%$ by the Scott-Knott test.

Table 3: Dry matter of weeds ( $\mathrm{g}$ ) at different times after germination of green manures in Itaquiraí, Mato Grosso do Sul. Agricultural year: 2010/2011

\begin{tabular}{lccc}
\hline & \multicolumn{3}{c}{ Days after emergence of green manures } \\
\cline { 2 - 4 } Green manures & $\mathbf{4 5}$ & $\mathbf{9 0}$ & $\mathbf{1 0 5}$ \\
\cline { 2 - 4 } & $1.48 \mathrm{~b} \mathrm{~A} *$ & $0.69 \mathrm{c} \mathrm{B}$ \\
Crotalaria juncea & $2.10 \mathrm{a} \mathrm{A}$ & $0.74 \mathrm{~b} \mathrm{~B}$ & $0.70 \mathrm{c} \mathrm{B}$ \\
Cajanus cajan & $2.31 \mathrm{a} \mathrm{A}$ & $0.85 \mathrm{~b} \mathrm{~B} \mathrm{~b} \mathrm{~B}$ & $0.29 \mathrm{~d} \mathrm{C}$ \\
Canavalia brasiliensis & $1.47 \mathrm{~b} \mathrm{~A}$ & $0.88 \mathrm{~b} \mathrm{~B}$ & $0.98 \mathrm{~b} \mathrm{~B}$ \\
Canavalia ensiformis & $1.01 \mathrm{c} \mathrm{A}$ & $0.56 \mathrm{c} \mathrm{B}$ & $0.96 \mathrm{~b} \mathrm{~A}$ \\
Pennisetum americanum & $1.06 \mathrm{c} \mathrm{A}$ & $0.63 \mathrm{~b} \mathrm{~B}$ & $0.50 \mathrm{c} \mathrm{B}$ \\
P. americanum/C. juncea & $2.32 \mathrm{a} \mathrm{A}$ & $0.41 \mathrm{c} \mathrm{B}$ & $0.13 \mathrm{~d} \mathrm{~B}$ \\
Mucuna aterrima & $1.52 \mathrm{~b} \mathrm{~A}$ & $0.67 \mathrm{~b} \mathrm{~B}$ & $0.54 \mathrm{c} \mathrm{B}$ \\
Sorghum bicolor & $1.05 \mathrm{c} \mathrm{A}$ & $0.20 \mathrm{c} \mathrm{B}$ & $0.13 \mathrm{~d} \mathrm{~B}$ \\
Mixture of green manures & $2.31 \mathrm{a} \mathrm{C}$ & $4.49 \mathrm{a} \mathrm{B}$ & $4.91 \mathrm{a} \mathrm{A}$ \\
Fallow (control) & & 19 &
\end{tabular}

* Means followed by the same small letter in the column and capital letter in the row are not significantly different at $5 \%$ by the Scott-Knott test. 
majority of weeds. In this evaluation, the mixture of green manures also had high performance at 45 and 90 DAE, promoting the highest rates of weed suppression (Tables 2 and 3 ).

Guilherme et al. (2007), studying a mixture similar to this study, found a high biomass production capacity and increased soil organic matter in the short term and also pointed out that the combination of different green manures increases the potential to raise the rate of biological activity of the soil and improve its fertility.

There was significant progress in the process of weed suppression by some species of green manure between 45 and 90 DAE (Table 3), which, however, became stabilized up to 105 DAE. This behavior was observed in the treatments with Crotalaria juncea, Cajanus cajan, Canavalia ensiformis, intercrop of Pennisetum americanum with Crotalaria juncea, mixture of green manures and Sorghum bicolor.

On the other hand, Canavalia brasiliensis, which presented low suppression at 45 DAE, showed significant improvement in weed suppression at 90 and 105 DAE. However, Pennisetum americanum, which promoted good suppression at 45 DAE, evolved up to 90 DAE, but significantly reduced weed suppression at $105 \mathrm{DAE}$ (Table 3).

The findings of Severino \& Christoffoleti (2001) corroborate the results of this study. They evaluated the effects of the amounts of green manure biomass on suppressing weeds and observed interactions between the amount of green manure used and the reduction in density and dry matter production of weeds; as the amount of green manure biomass increased, there was, in general, reduction in weed infestation.

The results of the control (fallow) (Tables 1, 2 and 3 ) showed that the exposed soil favors weed emergence. These results, according to Meschede et al. (2007), show that higher light incidence in the soil increase significantly the presence of weeds and reinforce the hypothesis that the physical effect is the main suppressor of weed species emergence.

Studying several legume species, Lopes et al. (2004) found effective weed control by a few legumes intercropped with cassava, however, those of slower development and lower shoot mass production had lower suppression levels, which was also observed in this study.

After the planting of cassava, all the green manure treatments continued to have the suppressive effect on weeds, especially those with the mixture of Mucuna aterrima, Canavalia brasiliensis and sorghum. The percentage of soil covered by weeds and the dry matter yield had a high ratio because, as the weeds provided a low soil cover, the dry matter produced by these plants was also reduced (Table 4).

Lorenzi (2012) reported that the total period of interference (PTPI) of invasive plants with the cassava crop comprises from emergence to four or five months after planting and can reduce production by more than $50 \%$, especially in the first 60 days after the budding started.

Thirty days after the planting of cassava, suppression of weeds was the greatest, reducing significantly in the evaluations carried out every month (60 and 90 days), i.e., the green manures have an important suppressive effect at the beginning of the cassava development ( Table 4 and 5).

Gabriel Filho et al. (2000) discussed that the cassava crop, due to factors such as leaf architecture and crop spacing, is highly susceptible to erosion, especially in the first 30 days, a period that can be characterized as critical in relation to erosion. Therefore, the use of systems that include green manure, associated with maintenance of crop residues on the soil surface is essential to achieve sustainable agriculture.

Table 4: Soil cover percentage (CSPD) and dry matter (MSPD) of weeds after the planting of cassava in Itaquiraí, Mato Grosso do Sul. Agricultural year: 2010/2011

\begin{tabular}{lcc}
\hline Grenn manures & CSPD $(\%)$ & MSPD $\left(\mathbf{t ~ h}^{-1}\right)$ \\
\hline Crotalaria juncea & $35.0 \mathrm{~d}^{*}$ & $1.57 \mathrm{~d}$ \\
Cajanus cajan & $40.4 \mathrm{c}$ & $1.79 \mathrm{c}$ \\
Canavalia brasiliensis & $30.4 \mathrm{e}$ & $1.28 \mathrm{e}$ \\
Canavalia ensiformis & $50.0 \mathrm{~b}$ & $2.18 \mathrm{~b}$ \\
Pennisetum americanum & $40.0 \mathrm{c}$ & $1.81 \mathrm{c}$ \\
P. americanum/C. juncea & $36.6 \mathrm{~d}$ & $1.63 \mathrm{~d}$ \\
Mucuna aterrima & $28.3 \mathrm{e}$ & $1.18 \mathrm{e}$ \\
Sorghum bicolor & $29.1 \mathrm{e}$ & $1.28 \mathrm{e}$ \\
Mixture of green manures & $28.3 \mathrm{e}$ & $1.22 \mathrm{e}$ \\
Fallow (control) & $68.7 \mathrm{a}$ & $3.16 \mathrm{a}$ \\
\hline CV $(\%)$ & 8.8 & 12
\end{tabular}

* Means followed by the same letter in the column are not significantly different at $5 \%$ by the Scott-Knott test.

Table 5: Soil cover percentage (CSPD) and dry matter (MSPD) of weeds at different times of evaluation, after the planting of cassava in Itaquiraí, Mato Grosso do Sul. Agricultural year: 2010/ 2011

\begin{tabular}{lcc}
\hline Time (days) & CSPD $(\%)$ & MSPD $\left(\mathbf{t ~ h \mathbf { ~ } ^ { - 1 } )}\right.$ \\
\hline 30 & $14.7 \mathrm{c}^{*}$ & $0.64 \mathrm{c}$ \\
60 & $38.0 \mathrm{~b}$ & $1.68 \mathrm{~b}$ \\
90 & $63.3 \mathrm{a}$ & $2.81 \mathrm{a}$ \\
\hline $\mathrm{CV}(\%)$ & 8.8 & 12 \\
\hline
\end{tabular}

* Means followed by the same letter in the column are not significantly different at $5 \%$ by the Scott-Knott test. 


\section{CONCLUSIONS}

Planting green manures before the cassava crop was effective in suppressing weeds and provided greater soil cover, indicating that the adoption of this practice integrated with the cassava crop is promising in the composition of crop arrangements in agroecological bases.

Green manures also have suppressive effect on weeds after their management (cut), especially in the early development of cassava, standing out the mixture of green manures, Mucuna aterrima, Canavalia brasiliensis and sorghum.

\section{REFERENCES}

Albuquerque JAA, Sediyama T, Silva AA, Carneiro JES, Cecon PR \& Alves JMA (2008) Interferência de plantas daninhas sobre a produtividade da mandioca (Manihot esculenta). Planta Daninha, 26:279-289.

Alvarenga RC, Costa LM, Moura Filho W \& Regazzi AJ (1995) Características de alguns adubos verdes de interesse para a conservação e recuperação de solos. Pesquisa Agropecuária Brasileira, 30:175-185.

Borghi E, Costa NV, Crusciol CAC \& Mateus GP (2008) Influência da distribuição espacial do milho e da Brachiaria brizantha consorciados sobre a população de plantas daninhas em sistema plantio direto na palha. Planta Daninha, 26:559-568.

Calegari A, Modardo A, Bulizani EA, Costa MBB, Miyasaka S \& Amado TJC (1993) Aspectos gerais da adubação verde. In: Costa MBB (Coord.). Adubação verde no sul do Brasil. $2^{\mathrm{a}}$ ed. Rio de Janeiro, ASPTA. 346p.

Calvo CL, Foloni JSS \& Brancalião SR (2010) Produtividade de fitomassa e relação $\mathrm{C} / \mathrm{N}$ de monocultivos e consórcios de guandu-anão, milheto e sorgo em três épocas de corte. Bragantia, 69:77-86.

Duarte Junior JB \& Coelho FC (2008) Adubos verdes e seus efeitos no rendimento da cana-de-açúcar em sistema de plantio direto. Bragantia, 67:723-732.

Erasmo EAL, Azevedo WR, Sarmento RA, Cunha AM \& Garcia SLR (2004) Potencial de espécies utilizadas como adubo verde no manejo integrado de plantas daninhas. Planta Daninha, 22:337-342.

Favero C, Jucksch I, Alvarenga RC \& Costa LM (2001) Modificações na população de plantas daninhas na presença de adubos verdes. Pesquisa Agropecuária Brasileira, 36:1355-1362.

Fernandes MF, Barreto AC \& Emídio Filho J (1999) Fitomassa de adubos verdes e controle de plantas daninhas em diferentes densidades populacionais de leguminosas. Pesquisa Agropecuária Brasileira, 34:1593-1600.

Fietz CR \& Fisch GF (2008) O clima da região de Dourados, MS. $2^{\mathrm{a}}$ ed. Dourados, Embrapa Agropecuária Oeste. 32p. (Documentos, 92).

Gabriel Filho A, Pessoa ACS, Strohhaecker L \& Helmich JJ (2000) Preparo convencional e cultivo mínimo do solo na cultura de mandioca em condições de adubação verde com ervilhaca e aveia preta. Ciência Rural, 30:953-957.

Guilherme DO, Costa CA, Martins ER, Sampaio RA, Teles Filho SC \& Cavalcanti TFM (2007) Utilização de coquetel de plantas usadas na adubação verde na melhoria das condições físicas e químicas do solo. Revista Brasileira de Agroecologia, 2:1445-1448.

Lopes CA, Abboud ACS, Tozani R, Pereira MB \& Costa EL (2004) Comparação entre a composição florística do banco de sementes do solo e da cobertura vegetal em área cultivada em mandioca e leguminosas consorciadas. Agronomia, 38:45-51.
Lorenzi JO (2012) Mandioca. Campinas, CATI. 129p. (Boletim técnico, 245).

Meschede DK, Ferreira AB \& Ribeiro JR (2007) Avaliação de diferentes coberturas na supressão de plantas daninhas no cerrado. Planta Daninha, 25:465-471.

Monquero PA, Amaral LR, Inácio EM, Brunhara JP, Binha DP, Silva PV \& Silva AC (2009) Efeito de adubos verdes na supressão de espécies de plantas daninhas. Planta Daninha, 27:85-95.

Nascimento AF \& Mattos JS (2007) Produtividade de biomassa e supressão de plantas daninhas por adubos verdes. Agroecología, 2:3338.

Okito A, Alves BJR, Urquiaga S \& Boddey RM (2004) Nitrogen fixation by groundnut and velvet bean and residual benefit to a subsequent maize crop. Pesquisa Agropecuária Brasileira, 39:1183-1190.

Oliveira TK, Carvalho GJ \& Moraes RNS (2002) Plantas de cobertura e seus efeitos sobre o feijoeiro em plantio direto. Pesquisa Agropecuária Brasileira, 37:1079-1087.

Pacheco LP, Leandro WM, Machado PLOA, Assis RL, Cobucci T, Madari BE \& Petter FA (2011) Produção de fitomassa e acúmulo e liberação de nutrientes por plantas de cobertura na safrinha. Pesquisa Agropecuária Brasileira, 46:17-25.

Padovan MP \& Almeida AS (2006) A multifuncionalidade das plantas daninhas nos agroecossistemas durante e pós-conversão. In: Padovan MP (Org.) Conversão de sistemas de produção convencionais para agroecológicos: novos rumos à agricultura familiar. Dourados, Edição do Autor. p.97-104.

Padovan MP, Motta IS, Carneiro LF, Moitinho MR \& Fernandes SSL (2011) Acúmulo de fitomassa e nutrientes e estádio mais adequado de manejo do Canavalia ensiformes para fins de adubação verde. Revista Brasileira de Agroecologia, 6:182-190.

Padovan MP, Motta IS, Carneiro LF, Moitinho MR \& Brito G (2012) Dinâmica de acúmulo de massa e nutrientes pelo milheto para fins de adubação verde em sistemas de produção sob bases ecológicas. Revista Brasileira de Agroecologia, 7:95-103.

Santos HG, Jacomine PKT, Anjos LHC, Oliveira VA, Lumbreras JF, Coelho MR, Almeida JÁ, Cunha TJF \& Oliveira JB (2013) Sistema brasileiro de classificação de solos. $3^{\mathrm{a}}$ ed. Brasília, Embrapa. 353p.

Santos IC, Mendes FF, Miranda GV, Galvão JCC, Oliveira LR, Souza LV, Guimarães LJM, Fontanétti A \& Faluba JS (2007) Avaliação de cultivares para produção orgânica de milho-verde e grãos em consorciação com mucuna-anã. Revista Brasileira de Agroecologia, 2:1141-1144.

Severino FJ \& Christoffoleti PJ (2001) Efeitos de quantidades de fitomassa de adubos verdes na supressão de plantas daninhas. Planta Daninha, 19:223-228.

Silva AGB, Guerra JGM, Gonçalves Junior M, Costa JR, Espíndola JAA \& Araújo ES (2011) Desempenho agronômico de mucuna verde em diferentes arranjos espaciais. Pesquisa Agropecuária Brasileira, 46:603-608.

Timossi PC, Wisintainer C, Santos BJ, Pereira VA \& Porto VS (2011) Supressão de plantas daninhas e produção de sementes de crotálaria, em função de métodos de semeadura. Pesquisa Agropecuária Tropical, 41:525-530.

Torres JLR, Pereira MG \& Fabian AJ (2008) Produção de fitomassa por plantas de cobertura e mineralização de seus resíduos em plantio direto. Pesquisa Agropecuária Brasileira, 43:421-428. 